\title{
Mobility, Telecommunication and Energy Regimes
}

\section{in Svalbard}

\author{
Andrian V. Vlakhov* \\ National Research University Higher School of Economics \\ 20 Myasnitskaya St., Moscow, 101000, Russia \\ Peter the Great Museum of Anthropology \\ and Ethnography (Kunstkamera) RAS \\ 3 University Emb., St. Petersburg, 199034, Russia
}

Received 01.03.2019, received in revised form 30.07.2019, accepted 08.08.2019

This paper deals with the role of mobility and telecommunication of the residents of Svalbard archipelago. The main focus of this study is the role of those factors in creating the energy regimes of the archipelago. The field study data shows that mobility and telecommunication are, first, intertwined factors of the local social space; second, their physical and social dimensions are also inseparable. The issues of mobility and telecommunication and their role in creating the local energy regimes are also an important topic of the public discourse of the Arctic policy-making.

Keywords: Svalbard, Arctic politics, mobilities, telecommunication, energy regimes.

The present research has been supported by the RSF project "Energy of the Arctic and Siberia: The Use of Resources in the Context of Socio-Economic and Environmental Changes" (No. 18-18-00309).

Research area: ethnography, ethnology and anthropology.

Citation: Vlakhov, A.V. (2019). Mobility, telecommunication and energy regimes in Svalbard. J. Sib. Fed. Univ. Humanit. soc. sci., 12(8), 1506-1521. DOI: 10.17516/1997-1370-0462.

\section{Introduction}

The archipelago of Svalbard, or Spitsbergen, is situated in the western part of the Arctic Ocean, being the northernmost part of the Kingdom of Norway. Svalbard was discovered by European mariners, namely Willem Barentsz, in the late $16^{\text {th }}$ century; due to its rich and various natural resources, the archipelago became an arena of political rivalry of many states for several centuries thereafter. This rivalry became significantly

(C) Siberian Federal University. All rights reserved

* Corresponding author E-mail address: avlakhov@gmail.com ORCID: 0000-0002-9099-8235

This work is licensed under a Creative Commons Attribution-NonCommercial 4.0 International License (CC BY-NC 4.0). 
acute in the late $19^{\text {th }}$ and early $20^{\text {th }}$ centuries, when the strategic importance of the Svalbard coal deposits increased dramatically. However, a diplomatic solution was found, and The Svalbard Treaty, the first ever international agreement concerning the Arctic, was adopted in 1920. The Treaty awarded the sovereignty over the archipelago to Norway; at the same time, all the signatories of the Treaty ${ }^{1}$ were granted the right to exploit the natural resources of Svalbard, and a regime of demilitarization and environment protection was extended over the entire archipelago (Åtland and Pedersen, 2008: 229).

During the $20^{\text {th }}$ century, nearly all the signatory states have ceased their activities in Svalbard due to the decrease of the importance of coal and, consequently, its prices; the only two major players remaining were Norway and the Soviet Union (later succeeded by Russia). For both states, their presence in the archipelago was a strategic issue: the important geographic position of Svalbard as an eastern/western outpost, as well as potential logistical and resource base, kept the Svalbard settlements alive through the Cold War time and into the post-Soviet period. Though proclaiming mutual trust and friendship in the official documents, the two local communities, Soviet and Norwegian, have been wary of each other and never maintained any significant relationship beyond the official communication (Jørgensen, 2004: 188-189).

The late 1980s brought many changes to the archipelago. The end of the Cold War and the crisis of the coal industry have undermined the very basis of both states' Svalbard strategies, and the two communities have established extensive business and grass-roots links. Nowadays, the archipelago is officially and essentially a zone of cooperation between Norway and Russia, as well as a laboratory for the post-industrial redevelopment: both communities are actively developing sustainable activities like tourism, research and education, thriving to secure a smooth transition of the archipelago into a non-industrial future. Norway has achieved significant progress along this road during the last three decades; Russia was delayed by the economic and political crisis of the 1990s, but has recently started to implement its new post-industrial Svalbard strategy — with significant success (Åtland and Pedersen, 2008: 231, 240).

However, the legacies of the past still play an important role in the life of Svalbard communities. The $20^{\text {th }}$ century history still persists in material and non-material

\footnotetext{
Fourteen parties signed the Treaty in 1920: Denmark, France, Italy, Japan, the Netherlands, Norway, Sweden, the United Kingdom, the United States, and several countries that were at the time "British overseas dominions": Australia, Canada, India, New Zealand and South Africa. Later, they were joined by the Soviet Union (1924), China and Germany (1925), and other countries (for official information, see: https://lovdata.no/dokument/NL/lov/1920-02-09).
} 
evidence, creating a link between two historical periods. The Russian and Norwegian communities remain relatively separated, both by natural and symbolic boundaries, though, as already mentioned, some progress has been achieved in this matter as there are no longer any political obstacles for communication between them. Setting aside the political issues, two most important aspects of these processes are mobility and (tele) communication - the basic means of establishing links between any communities, including those of Svalbard.

\section{Methodology and research question}

The present paper is a part of the larger research project aiming at the description of the life and structure of the Russian Svalbard community and the changes brought to the community by recent modernization project. The overarching study conceptualizes the Russian Svalbard settlements as single-industry towns (monogoroda), a type of settlement quite common in Russia in general and in its Arctic area in particular. The studies of single-industry towns, shared between economic and social sciences, take into account all the aspects of the life in the towns, including both economic prospects and the social interaction. The life of the Arctic single-industry towns has been thoroughly researched by many scholars, with the theoretical ground developed extensively by (Nuikina, 2014), (Riabova et al., 2013), etc. Another approach to these settlements, conceptualizing them as company towns, is adopted in the Western research tradition; see, for example (Barnes, 2005) or (White, 2012), while a comprehensive analysis can be found in (Carson and Carson, 2014).

In this study, I address the aspects of the social interaction in the Svalbard singleindustry towns, focusing on the issues of mobility and telecommunication. Both these issues have extensive background in the social research; however, I do not focus on their profound theoretical description, using them as ready-made concepts instead and applying them to the field data. In my study, I follow the approach to mobility (or rather mobilities in plural) as an overarching concept of describing the spatial dimension of social interaction, as defined in (Cresswell, 2011). The concept of remoteness defined as combining both spatial and social aspects is taken from (Bauman, 1990: 147-148). The communication, one of the central concepts for the Science and Technology Studies, is defined very broadly as exchange of information between any subjects; in this study, the practical aspect of communication between people and communities is in focus, thus the term "telecommunication" is also used in reference to both technical means of communication and the remoteness of communicating subjects. 
The study is based on the in-depth interviews conducted during the field research between 2014 and 2018, supplemented with participant observation in the Svalbard settlements. The field study had a strong bias towards the data from Russian community as its description was the primary objective of the study; however, the study includes observation conducted in Norwegian community and interviews with the Norwegian and international actors as well. The entire study thrives to find balance between the viewpoints of actors from different levels (i. e. decision-makers, experts, employees of different companies and their branches, and the grass-roots actors) to present the aspects of life in Svalbard as a multitude of voices, following the framework of the actor-network theory; for its application to the description of the Arctic, see (Avango et al., 2013).

The general research question of this study deals with the role of mobility and telecommunication in the life of Svalbard. What role do they play in the everyday life of the local communities, how do they shape the communication between them, construct the borders and help to overcome them at the same time? Answering these questions can contribute to better understanding of the role of natural and symbolic boundaries in Svalbard and to further description of post-industrial transition processes in the archipelago.

\section{Settlements in Svalbard: so close, so remote}

The history of settlements in Svalbard can be securely traced back to the early $17^{\text {th }}$ century, when the archipelago was discovered by Western European whalers subsequently founding several major whale processing towns in various parts of Spitsbergen (called that name until the early $20^{\text {th }}$ century) (Fig. 1). Many Russian researchers argue that there was significant Russian presence in Svalbard since the $15^{\text {th }}$ century, whereas most Scandinavian scholars state that the Russian whaling and fishing industry in the archipelago did not appear before 1700. These discrepancies are being constantly discussed in the historical research works (see, for example, (Hacquebord and Avango, 2009: 30) and (Hultgreen, 2002: 128-130)); however, the scholarly community agrees that there is significant Russian cultural heritage in Svalbard that is at least 2-2,5 centuries old. There is also historical evidence of contacts between Russian and Western whalers in Svalbard, but these contacts have never been extensive due to the cultural and language barriers (Avango and Hacquebord 2009: 30-31). As mentioned in the introduction, the new era of Svalbard came with the discovery of coal and other mineral resources. Today, only Norway and Russia are significant players in the archipelago. The infrastructure developed by other actors (Sweden, the 


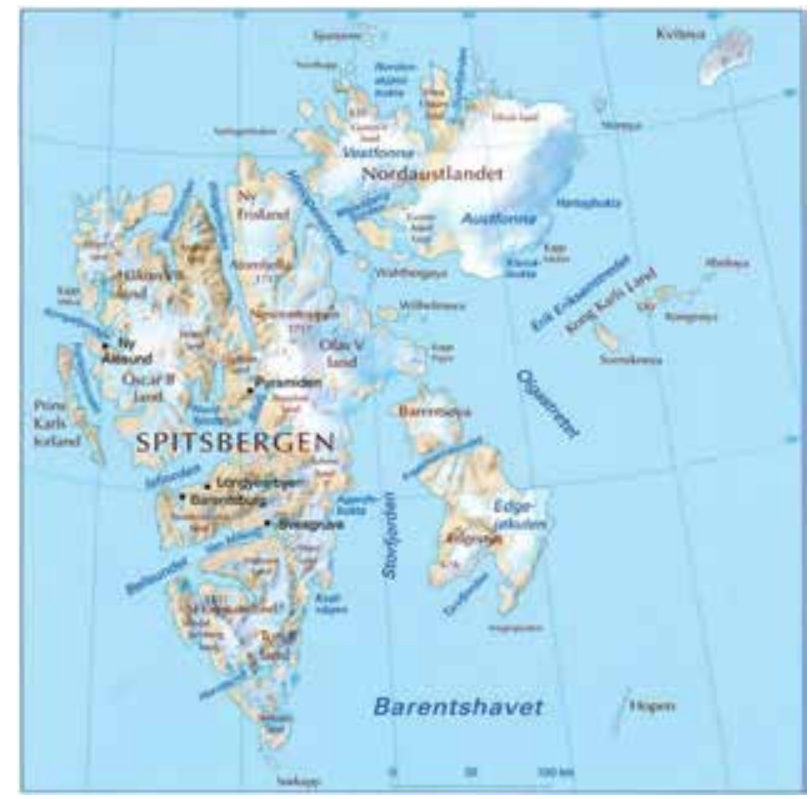

Fig. 1. Map of Svalbard.

Source: http://www.mappery.com/map-of/Svalbard-Physical-Map

Netherlands, the United States etc.) was inherited by the two countries, adapted to own needs or left to decay.

Today, there are four active settlements at the archipelago. Norway possesses three: Longyearbyen, Ny-Ålesund and Sveagruva, with American-founded Longyearbyen as the "capital" of the entire archipelago, the touristic, educational and logistical center and the seat of governor (sysselmannen); Ny-Ålesund, previously a mining settlement, now functions as an international research station, while Sveagruva is still operating as a mining site. Russia operates one full-scale settlement, the town of Barentsburg, home for the coal mine and for ca. 500 people. There are also minor Russian activities in Pyramiden (mining terminated and town abandoned in the late 1990s, but the infrastructure is still used for touristic activities). Russia also possesses two towns, Grumantbyen and Coles Bay (Colesbukta), abandoned in the 1950s, but with prospects for future mining.

These settlements, together with several small research and tourism bases, are situated in or very close to the region of Isfjørden, the massive inlet of the Greenland Sea inside the Western Spitsbergen island (Fig. 2). They form a kind of network where the nodes are relatively well-connected through the main hub in Longyearbyen (also serving as the main air- and seaside entrance to the archipelago) with a secondary hub in Barentsburg. There are various means of transportation available: helicopter pads 


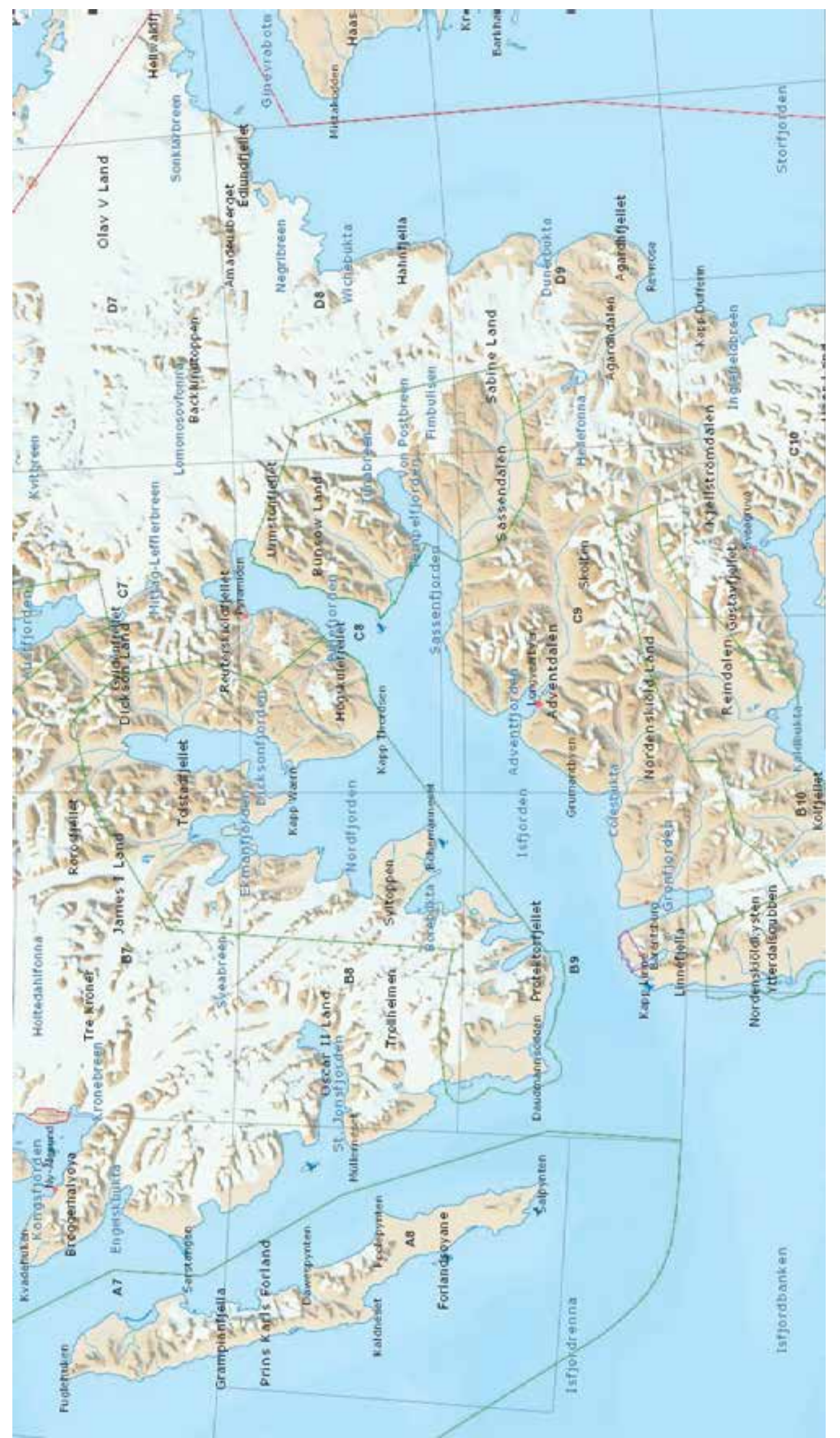

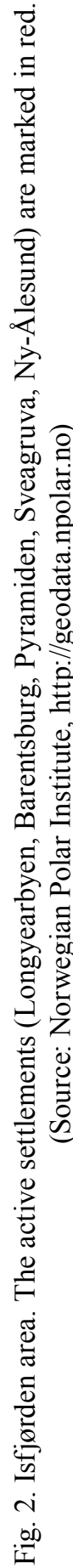


and/or landing strips in each active settlement and in many research sites, sea transport around Isfjørden and also in every part of the Svalbard coastline, and extensive snow scooter trail network in the inhabited area. The means of telecommunication are also relatively well-developed: there are cable connection between settlements, mobile networks of the Norwegian and Russian carriers, satellite connection to the remote areas, wired networks inside the settlements, and postal mail service. It should be also mentioned that the archipelago is well-connected to the outside world as well: there are regular and chartered passenger and cargo air services to Norway, Russia and other countries as well as significant marine activity (cargo and cruise vessels from Europe), and there is a high-speed optic fiber connection to the Norwegian mainland.

However, Svalbard remains also a place of high remoteness, concerning both mobility and communications. The spatial remoteness is a consequence of the local natural setting: Svalbard consists mostly of mountains, vales and fjords, with most settlements located at the rare patches of flat land. There are no roads between any two major settlements: the road network of Longyearbyen, the most extensive in the entire archipelago, only goes tends as far as the airport and the nearby research stations. The cost of transportation between settlements is rather high, while the efficiency of such transportation is also significantly affected by the climatic and weather conditions. The human mobility is therefore mostly limited to the confines of the town, which is augmented by the legal regulations (restricting movements in the wilderness due to environmental protection legislation and polar bear attack hazard). The mobility is also linked to the means of transportation (ability to move is a privilege of those in possession of a car/snow scooter) and is also a marker of a social status (usually that of tourist industry employees or government workers). It should also be noted that individual mobility is quite rare for Svalbard: most spatial movements are made in groups.

Concerning communication, the situation is similar: its success depends on the access to the technologies possessed by certain social groups (and, it should be said, not as well developed as in the mainland: some settlements, like Pyramiden, remain outside of the communication framework). In addition to that, extensive communication is mostly restricted to the specific settlements (though significant progress has been achieved here in the recent years) while the need for communication in the wilderness areas remains highly important.

In general, the framework of mobility and communication in Svalbard can be described as manifold: while significant networks of moving and communicating actors exist in the archipelago, many practical issues make these networks complex 
both in structure and quality. In the following sections, I attempt to further analyze the frameworks of mobility and communication in Svalbard, suggesting that these aspects of the social interaction are both its vital part and a catalyst of recent changes.

\section{"I can't say I move around too much here": Svalbard mobilities}

There are several ways of movement that can be used for moving across the archipelago of Svalbard. They can be roughly divided into three categories: ground, water and air movement, each with several various means of transportation available. The system of ground transportation is the most extensive: it includes the road networks in the settlements and to the sites adjacent to them, the hiking paths in and around the inhabited Isfjørden area and also a vast networks of snow scooter trails covering a significant part of Svalbard landmass (snow scooter movement, however, is limited by the Norwegian environmental regulations). The air transport is the most far-reaching (serving even the most remote corners of the archipelago for research and governance purposes), consisting of Longyearbyen airport handling large jets from the mainland along with smaller airplanes and helicopters serving all other remote communities. The water transport includes large cruise and cargo ships coming from the mainland as well as the smaller vessels (boats and speedboats) used for local traffic and sightseeing tours. Thus, the transportation network of Svalbard can be described as both extensive and relatively well developed.

However, the actual mobility of the people living in the archipelago is not as well developed as the possibilities of movement described above. There are several factors that hinder the mobility in Svalbard, the most important of these being the natural conditions and the social implications of mobility. The first of these factors, the natural obstacles, has diverse manifestations: first of all, the land surface of Svalbard is quite rough, making the shortest routes unavailable and dependent on the quality of machines and fuel. This makes the already long distances between settlements and other significant points of the archipelago even longer. Then, there are climatic factors affecting movement: some means of transportation are unavailable during certain periods (e. g. snow scooters during summer and autumn; or smaller watercrafts during winter), and their use can be extremely uncomfortable and dangerous during the periods of bad weather. In addition to that, mobility is also affected by the general remoteness of Svalbard from the mainland: air and sea transportation to/from Europe is highly dependent on the natural conditions, including sea ice and atmospheric status, 
and so are the local communities since all their supplies are being brought from the mainland. In general, the natural conditions of Svalbard are considered the primary reason why everyday mobility in the archipelago is not well developed, cf. (1):

(1) Well, I can't say I move around too much here. There are actually not so much destinations, and it's not easy to go anywhere even if you want to: to Longyearbyen, it's a two-hour scooter ride, you can't see a thing because of falling snow, and the road is extremely bumpy. Oh, and I forgot to add that if you break the scooter you'll have to pay for its repair $\left(F / 43 / H^{I}\right)$.

This last observation provides a good link to the second set of factors hindering mobility in Svalbard, which are the social ones. The first thing worth mentioning is the access to mobility, which is a significant resource in all settlements of the archipelago. In Norwegian communities, though some means of transportation are publicly available for purchase (snow scooters, cars and speedboats), the price level is usual for Norway (that is, one of the highest in the world), and the possession of a car or a scooter also involves significant service costs. In addition to that, there are different implications of a possession concept there: property purchased in Svalbard can only be used there (it's virtually impossible to transport large objects to the mainland), so possessing a vehicle or a vessel only pays off if the owner professionally transports goods or people. In the Russian community, a very special type of possession concept is adopted: there is no large private property as virtually all the infrastructure is owned by the operating mining company, Trust Arcticugol', therefore the means of transportation can only be used for official needs and not for leisure. This means that no inhabitant of the Russian towns (except tour guides who sometimes attempt private trips) can move around the archipelago freely: they are restricted by both legal regulations and the inaccessibility of transport. This is often a source of heavy frustration for them, cf. (1) above and the following (2):

(2) I would greatly like to go to Longyear[byen], have a look at how people live here, maybe make friends; well, visiting their supermarket wouldn't be bad as well. But I can't do that here, it's technically impossible: all the scooters are with the tour guides, and of course no helicopter will fly me there, it's too expensive $(F / 29 / L)$.

\footnotetext{
The following style is used for interview transcript citations: Gender/Age/Education. $\mathrm{M}=$ male, $\mathrm{F}=\mathrm{female}$; $\mathrm{H}=$ higher education (college or university degree), $\mathrm{L}=$ level of education lower than $\mathrm{H}$. Age is given for the date of interview.
} 
As usual, when the access to the resource is limited, those in possession of it gain a significant share of social capital through controlling and/or providing such access to the resource. This is especially important in the Russian community where the people facilitating and providing mobility (helicopter team, scooter technicians, tour guides etc.) easily obtain rather high social status and significant benefits even if they happen to have a lower position by other parameters (age, gender, ethnicity etc.). The access to mobility can be traded, becoming a commodity: exchanged for material goods or for other services, e. g. communication (see below). Such exchange networks are the backbone of the local economy (for further details, see Vlakhov, 2015).

Another issue worth discussing in connection with mobility is tourism. In Svalbard, moving around the archipelago is a prerogative of tourist business: the tour companies possess the majority of transport of all kinds available, so they are able to set the framework of mobility in the archipelago. This is reflected in the price of transportation (for example, a one-way trip from Longyearbyen to Barentsburg costs no less than 1,000 Norwegian kroner (equal to ca. 125 US dollars), making it impossible for the Russian town inhabitants to travel to the Norwegian communities) and also affects the symbolic perception of movement. People who work at the archipelago (e. g. in the mining industry) consider "going here and there" to be a trait of touristic approach to Svalbard, not appropriate for its permanent settlers, cf. (3):

(3) I came here to work and to make money, not to wander around just wasting my time. Riding a car is what I do in the mainland during my vacation, when I have enough free time $(M / 32 / H)$.

One should also mention the legal regime of Svalbard which plays a significant role in the local mobility framework. The entire archipelago is protected by the Norwegian environmental legislation prohibiting humans from entering more than $2 / 3$ of its territory and imposing strict regulation on movement in the remaining parts (e. g. riding snow scooters is only allowed along certain routes between settlements). In addition to that, severe regulations concerning human safety are active in the archipelago: a person or a group should be armed with a rifle to enjoy the right of free movement outside the settlements due to the polar bear attack hazard. This is an important trait of the local discourse, so many people prefer not to travel outside the settlements unless this is unavoidable, thus preferring safety to mobility. Finally, for many people (first and foremost Trust Arcticugol' employees) it is considered against the rules to leave the settlement due to possible emergency work engagement; breach of this rule 
most probably results in the offender's losing the job and subsequent departure from Svalbard.

In general, the framework of mobility in Svalbard is complex: there are many various types of mobility and transportation available, but there are also numerous limitations for their use by most of the Svalbard population. In this context, the ability to move becomes an important drive of societal changes: the access to transportation functions as a commodity which prompts many local inhabitants to make life-changing choices like moving to another settlement or changing the occupation. The mobility is intertwined with both natural and social aspects of living in Svalbard, thus playing an active role in creating a unique landscape of the archipelago; in addition to that, it has strong links to another aspect of social interaction in Svalbard, namely the communicative one. In the next section, I'm focusing on describing the communicative system of the archipelago.

\section{"We're living here like at the North Pole": telecommunications in Svalbard}

Telecommunication is also a good example of how the access to technologies can become a definitive factor in the social interaction. The Svalbard telecommunication system is not a uniform network, but rather a set of networks. The Norwegian community in Longyearbyen (ca. 2100 people, see (Statistics Norway, 2016)) enjoys access to the most recent technologies: high-speed internet connection in every household, 4G mobile networks, satellite TV and radio, etc. All other communities have limited access to telecommunications or no access at all; for example, Barentsburg has only recently acquired publicly available wired Internet access and broadcast channels, with cellular network made available just several years before; whereas Pyramiden still features a tourist attraction of "cell pole" — a metal construction at the hill top which is the only spot in the entire town where cellular connection is possible (during fine weather).

In such settings, access to the technologies becomes a privilege which defines many aspects of social interaction in the settlements. In Barentsburg, the right to use the internet connection is a commodity ${ }^{1}$ shared among the members of a privileged group (roughly correlating with IT department and tourism office), thus becoming a tool of social capital development. By providing Internet connection to other members

\footnotetext{
Or at least was - until very recently. In late 2015, the broadband cable has been finally delivered to Barentsburg after several failed attempts of signing a contract with Norwegian telecom operator; the relevant part of the fieldwork has been conducted before these changes.
} 
of the community, the members of this group get necessary resources, both material and symbolic. For example, one of the network administrators used to exchange the opportunity of using his official-use internet connection for alcoholic beverages and delicacies, while one of the school teachers also allowed their friends to use the school connection in exchange for fresh food and fishing equipment. Another interesting example of how the access to technologies is functioning in Barentsburg is (4):

(4) Shortly after my arrival to Barentsburg, I felt the need to communicate with my family who were still in the mainland at that time. I quickly found out that the only way to get enough speed for video call is to bribe someone working in the mine office. And it happened that everyone there had their own price: some demanded vodka, some demanded fresh fruit from Longyearbyen. In the end, we've agreed on two chocolate bars and several new movies I've brought from the mainland $(M / 30 / H)$.

Many of my informants, when describing the communication framework of Svalbard, compared it to the mainland situation. In their opinion, Svalbard is a place where the knowledge of technologies and the habit to use them becomes obsolete, so it is necessary to revive the seemingly forgotten practices of the past. This intensifies the sense of isolation and remoteness created by the impaired mobility, also reinforcing the identity of living "in the middle of nowhere" and "at the world's end", cf. (5):

(5) So it looks as if we're living here the same way as people in the 1980s did: no internet, limited phone connection; that's why I often say that we're living here like at the North Pole or in the high mountain village: no connection to the outside world $(F / 38 / L)$.

Following these, we can roughly define two categories of the local population: those who deem the communicative isolation and remoteness to be a drawback of the life in Svalbard, and those who come to the archipelago precisely for that isolation and remoteness ${ }^{1}$. The identity of the latter group cannot be defined clearly: in some cases, these are people thriving to escape from the outside world, its "hustle and bustle" and problems forever; in other cases, they just hope to take a break from the familiar scenery for a year or two and get some fresh experience. Nevertheless, extreme cases of

'The use of this term "local population" is somewhat ambiguous for Svalbard: there are very few people in the entire archipelago that have been living there for their entire lives or at least for more than 20 years. The population of the Russian towns, for example, mostly consists of people bound by short-term (one to five years) contracts. 
escapism are rare for Svalbard: the ultimate hermits eventually become local legends, like the "Soviet-style" tour guide in Pyramiden or "the mad German" living outside Longyearbyen; their public image is generally that of slightly insane persons, certainly not an example of a prototypic Svalbardian.

The former group, the people frustrated by the lack or deficiency of telecommunication, is also heterogeneous: the longing for technologies and communication does not correlate with age, gender, education level or any other social parameter. A good example here is the population of Barentsburg: during my fieldwork, numerous people manifested their profound experience in using modern telecommunication technologies, most notably a cook in her sixties and a group of seven-year-olds from the first-year school class. This group, having become used to the use of communicative technologies in their everyday life in the mainland, attempts to develop substitutes for the missing technologies and is thoroughly experienced in all the technical details of the processes. For example, nearly everyone in Barentsburg know the best places for cellular connection and the worst weather conditions affecting it; there are groups of people creating joint funds for using the expensive Norwegian mobile connection for video calls to the mainland. In most cases, these people produce extensive narratives justifying the need for technologies and are active in attempting to change the current situation (e. g. submitting pleas to the governing bodies).

It should also be noted that the telecommunication inside the settlement and the outside-directed one are two very different concepts. While the "internal" communication is relatively easy and can be accessed by virtually every member of the community, the external communication is always a cause of anxiety. In these conditions, it is the need for unhindered external communication that becomes a significant driving force of the change in Svalbard: for example, the development of the long-expected broadband connection in Barentsburg or the mobile network connection in remote Norwegian towns (Ny-Ålesund, Sveagruva) several years ago was an important part of the local discourse concerning the futures of the settlements. If the settlement is equipped with high-quality telecommunication facilities, it is more likely that the local population manifest higher hopes for its post-extractive redevelopment and the probability extending the term of their stay in the archipelago.

In general, the current state of the telecommunications development in Svalbard and the locals' attitude towards the communicative technologies vary. The technologies are developed quite unevenly throughout the archipelago, though the less-developed areas are now experiencing significant progress. The population displays different attitudes 
towards the state and conditions of such development, with both positive and negative perception of Svalbard as a well-connected place that is to become real in the near future. However, these attitudes differ greatly from what can be found in other Arctic areas (Danker, 1994: 50) due to the structure of Svalbard population, especially in the Russian settlements: most people become used to the well-developed communicative networks in the mainland: they are experienced users rather than novices who find themselves in different conditions in the archipelago. Nevertheless, there is also a significant group of "communicative escapists" that praise Svalbard as the wilderness area where there are still few digital technologies available.

\section{Discussion and conclusion}

As we stated in the introduction, the legacies of the past still play an important role in the life of Svalbard communities. The communities of the archipelago remain relatively remote from each other, both spatially and in terms of cultural and historical identities. This persisting remoteness is defined by two major aspects: mobility and (tele)communication, which are manifested in many forms in all local communities.

There are two most important and distinctive traits of mobility and telecommunication in Svalbard. First, the interconnection between physical and social dimensions of these concepts, with one dimension defining another (cf. the access to the technologies affecting the general mobility of Russian town inhabitants; or the successful overcoming of physical obstacles by people in urgent need of communicating to their relatives). Second, these two overarching concepts which the study is focusing on are also closely linked to each other, becoming inseparable in many cases. Being (or feeling) remote in Svalbard means both physical remoteness that can be overcome through access to transport, and informational remoteness that can be neutralized by means of telecommunication. Thus, we should rather be speaking about the uniform concept of communication covering both aspects, which can be used as a basis for further field studies in the archipelago.

Finally, we should mention that the concepts of remoteness and communication are of high importance for political and historical discourse of and about Svalbard. As mentioned previously, a path dependency (Carson and Carson, 2014: 463) exists for Svalbard communities: separated by the Cold War and other issues of history and politics, the Russian and Norwegian communities remain relatively remote from each other, preserving the material and non-material legacy of the past. In this respect, the successful development of communication between two communities (including both 
spatial and social aspects) can become a means of overcoming this legacy of the past, which is the ultimate goal stated in the political declarations of both countries. Such processes, which have already started at the grass-roots level, can be used for building the post-industrial futures of Svalbard. Taking this into account, it should be finally mentioned that the status-quo of Svalbard communicative systems described in this study is changing rapidly, and these rapid changes are to be monitored in further field studies.

\section{References}

Åtland, K., Pedersen, T. (2008). The Svalbard Archipelago in Russian Security Policy: Overcoming the Legacy of Fear - or Reproducing It? In European Security, 17: 2-3, 227-251.

Avango, D., Hacquebord, L. (2009). Settlements in an Arctic Resource Frontier Region. In Arctic Anthropology, 46, (1-2), 25-39.

Avango, D., Nilsson, A.E., Roberts, P. (2013). Assessing Arctic futures: voices, resources and governance. In The Polar Journal, 3: 2. DOI: 10.1080/2154896X.2013.790197

Barnes, T.J., Hayter, R., \& Hay, E. (2001). Stormy weather: Cyclones, Harold Innis and Port Alberni, BC. In Environment and Planning A, 33, 2127-2147. DOI: 10.1068/a34187

Bauman, Z. (1990). Thinking sociologically. Oxford: Basil Blackwell Ltd.

Carson, D.A., Carson, D.B. (2014). Mobilities and Path Dependence: Challenges for Tourism and "Attractive" Industry Development in a Remote Company Town. In Scandinavian Journal of Hospitality and Tourism, 14: 4, 460-479, DOI: 10.1080/15022250.2014.967997

Cresswell, T. (2011). Mobilities I: Catching up. In Progress in Human Geography, 35 (4): 550-558.

Danker, P. (1994). Telecommunications in Greenland — challenges and solutions. In Telektronikk, 90 (3): 48-51.

Hultgreen, T. (2002). When Did the Pomors Come to Svalbard? In Acta Borealia: A Nordic Journal of Circumpolar Societies, 19: 2, 125-145.

Jørgensen, J.H. (2004). Svalbard: Russiske persepsjoner og politikkutforming. In Internasjonal politikk, 62/2, 177-197.

Nuikina, E. (2014). Making a viable city: visions, strategies and practices. Unpublished doctoral thesis. Vienna: Universität Wien. 
Riabova, L., Didyk, V., Korchak, E., Bashmakova, E., Emelyanova, E. (2013). Arkticheskie monogoroda Rossiiskoi Federatsii: sotsialniye problemy, puti ikh resheniia i rol' resursnykh korporatsii [Single-industry towns of the Russian Arctic: social challenges, possible solutions and the role of resource corporations]. In Korporativnoe upravlenie i innovatsionnoe razvitie ekonomiki Severa, 3.

Statistics Norway (2016). Befolkningen på Svalbard, 1. januar 2016. Available at: http://www.ssb.no/befolkning/statistikker/befsvalbard/halvaar/2016-04-07 (accessed: 28.02.2019).

Vlakhov, A. (2015). Town modernization at Barentsburg: past, present and future of the Russian Svalbard. Paper presented at the In the Spirit of the Rovaniemi Process conference (November 24-26, 2015, Rovaniemi, Finland).

White, N. (2012). Company towns: Corporate order and community. Toronto: University of Toronto Press.

\title{
Мобильность, коммуникации и энергетические режимы на архипелаге Шпицберген
}

\author{
А. В. Влахов \\ Нацииональный исследовательский университет \\ «Высшая школа экономики» \\ Россия, 101000, Москва, Мясницкая ул., 20 \\ Музей антропологии и этнографии \\ им. Петра Великого РАН (Кунсткамера) \\ Россия, 199034, Санкт-Петербург, Университетская наб., 3
}

\begin{abstract}
В статье анализируется роль мобильности и телекоммуникаиий в жизни арктического архипелага Шиицберген. Особое внимание уделяется роли этих факторов в формировании энергетических режимов архипелага. Материалы полевых исследований показывают, что мобильность и коммуникации являются неотделимыми друг от друга факторами, чьи физическое и сочиальное измерения тоже тесно переплетены. Вопросы мобильности и коммуникации, а также их роль в формировании энергетических режимов оказываются важным фактором публичного дискурса об архипелаге.
\end{abstract}

Ключевые слова: Шпицберген, арктическая политика, мобильность, коммуникации, энергетические режимы.

Работа выполнена за счет гранта Российского научного фонда (проект № 18-1800309), проект «Энергия Арктики и Сибири: использование ресурсов в контексте сочиально-экономических и экологических изменений».

Научная специиальность: 07.00.07 - этнография, этнология и антропология. 